UDC 614.3: 543.001.6:546

DOI: $10.21668 /$ health.risk/2018.2.13.eng

\title{
SEPARATE QUONTITATIVE DETERMINATION OF ORGANIC AND NON-ORGANIC ARSENIC IN SEA PRODUCTS
}

\author{
U.S. Kruglyakova, O.V. Bagryantseva, A.D. Evstratova, A.D. Malinkin, \\ I.V. Gmoshinskii, S.A. Khotimchenko
}

Federal Research Center for Nutrition, Biotechnology and Food Safety, 2/14 Ust'inskiy lane, Moscow, 109240, Russian Federation

The performed research is truly vital, as As (arsenic) concentration in food products is now of great interest. The US ATSDR and EPA enlist As among the most toxic substances which are dangerous for human health.

We suggest a procedure for separate quantitative mass fraction determination for organic (oAs) and nonorganic (iAs) arsenic compounds in sea products with solid phase extraction (SPE) application combined with atomic adsorption spectrometry. Samples were prepared according to the following procedure: liquid extraction phase with simultaneous As (III) oxidation into As (IV) with hydrogen peroxide and As (V) extraction into a 0.055 $M$ liquid phase with hydrochloric acid. Arsenic organic and non-organic compounds were separated via solid phase extraction with Strata SAX cartridges (Sorbent Lot Number: S208-0058). To quantitatively assess the obtained samples, we applied atomic-adsorption techniques for As determination with "KVANT-2A-GRG" spectrometer according to the State Standard 51766-2001. We revealed that common As concentration didn't conform to fixed standards in 8 out of 17 analyzed samples (2 shrimps, 1 crab, 1 fish, and 4 seaweeds). However, iAs concentration was significantly lower than oAs concentration in all the samples. 6 out of 17 analyzed samples didn't contain any iAs within detection limits $(0.1 \mathrm{mg} / \mathrm{kg})$, and apparently all the As concentration occurred due to its organic compounds. The suggested procedure for separate oAs and iAs detection is relatively simple in terms of devices applied in it, and quite cheap, as SPE cartridges needed to perform it can be re-used after re-conditioning. This procedure, after a proper metrological validation, can be implemented in most laboratories which are certified to examine chemical safety of food products. sessment.

Key words: arsenic, non-organic form, solid phase extraction, atomic-adsorption spectrometry, risk as-

Arsenic (As) is a chemical element of the fourth period 15 th group in the periodic system. The electron shell structure: Ar $3 d^{10} 4 s^{2} 4 p^{3}$. According to the materials presented by A. Gomez-Caminero et al.
[1], As is a metalloid found in the structure of rocks, soil and groundwater in an average concentration of $2 \mathrm{mg} / \mathrm{kg}$ in inorganic and organic forms. The major sources of environment anthropogenic pollution with

(C) Kruglyakova U.S., Bagryantseva O.V., Evstratova A.D., Malinkin A.D., Gmoshinskii I.V., Khotimchenko S.A., 2018

Ul'yana S. Kruglyakova - a post-graduate student at Laboratory for Food Toxicology and Nanotechnologies Safety Assessment (e-mail: ulyana-kruglyako@mail.ru; tel.: +7 (495) 698-53-68).

Ol'ga V. Bagryantseva - Doctor of Biological Sciences, Leading Researcher at Laboratory for Food Toxicology and Nanotechnologies Safety Assessment (e-mail: olga bagryanseva@mail.ru; tel.: +7 (495) 698-54-05).

Anna D. Evstratova - Research Assistant at Laboratory for Food Toxicology and Nanotechnologies Safety Assessment (e-mail: anya.evstratova@mail.ru; tel.: +7 (495) 698-53-68).

Aleksei D. Malinkin - Researcher at Laboratory for Food Products Chemistry (e-mail: sindar7@mail.ru; tel.: +7 (495) 698-57-36).

Ivan V. Gmoshinskii - Doctor of Biological Sciences, Leading Researcher at Laboratory for Food Toxicology and Nanotechnologies Safety Assessment (e-mail: gmosh@ion.ru; tel.: +7 (495) 698-53-71).

Sergei A. Khotimchenko - Doctor of Medical Sciences, Professor, Head at Laboratory for Food Toxicology and Nanotechnologies Safety Assessment (e-mail: hotimchenko@ion.ru; tel.: +7 (495) 698-52-35). 
As are the extraction and burning of fossil fuels, using arsenic pesticides in agriculture, disposal of chemical weapons stockpiles, and using wood preservatives containing As. In most cases, human exposure to inorganic As (iAs) occurs through contaminated groundwater (drinking water, water used for cooking, and for irrigation of agricultural land). Along with this, people are regularly exposed to As through the consumption of products from aquatic organisms (fish, and shellfish and algae of sea fishery: mollusks, crabs, squid, seaweed, etc.), capable of As bioaccumulation in significant amounts from sea water.

The processes of metabolism and As bioaccumulation in a human body cause active interest in the scientific society [2]. The European Food Safety Agency (EFSA) data show a serious problem caused by As content in food products for public health in the world. The US Agency for Toxic Substances and Disease Registration (ATSDR) and the US Environmental Protection Agency (EPA) enlisted As among the most toxic substances to human health [3].

In toxicological terms, As compounds refer to "thiol poisons" that block sulfhydride groups of functionally significant proteins, including enzymes. A critical contribution to As toxicity is apparently made by its ability to stimulate reactive oxygen species formation, induce an excessive expression of growth factors, influence the transcription of genes indirectly, induce immunosuppresion and apoptosis [4]. iAs compounds are considered as the most dangerous. And trivalent As, as a rule, is more toxic. According to the International Agency for Research on Cancer
(IARC), iAs refers to carcinogens of Group 1 (substances with proven carcinogenic activity for humans) [5]. Unlike inorganic forms, the organic derivatives of As (oAs), the most common in seafood and seaweed, are considered low-toxic, according to the world literature, and in the IARC documents referred to as the "non-classified, in terms of human carcinogenicity" (Group 3). In this regard, their toxicological assessment in food products is not carried out [6-10].

In Russian Federation and EAEC countries, the method of atomic absorption spectrometry is currently adopted to assess As content in food products, which makes it possible to quantify the total As content only without fractionation into iAs and oAs. (TR CU 021/2011 ${ }^{1}$ ). The permissible levels of total As in food products, according to Technical Regulations "On Food Safety" (TR CU 021/20111) vary from 0.1 $\mathrm{mg} / \mathrm{kg}$ in raw milk to $5.0 \mathrm{mg} / \mathrm{kg}$ in shellfish and algae, and seaweed (in terms of product wet weight). It is these parameters that are used in hygienic assessments, studies, inspections [11-15]

Our research goal of the given study was to develop a procedure for separate determination of iAs and oAs content in seafood (fish, shrimp, squid, mussels, seaweed).

Materials and methods. Fish and non-fish objects of sea fishery (mollusks, crabs, squid, seaweed) purchased in Moscow consumer market were chosen as objects of study.

Reagents used: a standard As sample (a solution with As (III)mass concentration of $0.1 \mathrm{mg} / \mathrm{cm}^{3}$ ) produced by EcoAnalytical Association "Ecoanalytika", 33\% special

\footnotetext{
${ }^{1}$ TR TS 021/2011. O bezopasnosti pishchevoi produktsii: tekhnicheskii reglament Tamozhennogo soyuza [On Food Safety: Technical Regulations of the Customs Union]. Evraziiskaya ekonomicheskaya komissiya. Available at: http://www.eurasiancommission.org/ru/act/texnreg/dep-texreg/tr/Pages/PischevayaProd.aspx (15.03.2018)
} 
purity hydrogen peroxide, according to $\mathrm{CU}$ 6-02-570-75 $5^{2}$, methanol h.p., according to the State Standard GOST 6995-773 chloric acid $(\mathrm{HCl})$, part by weight, mass fraction $\geq 37 \%, \rho \geq 1.15 \mathrm{~g} / \mathrm{cm}^{3}$, according to GOST $3118-77^{4}$, ammonium carbonate, mass fraction $\geq 99.999 \%$ according to the State Standard GOST $3770-75^{5}$, acetic acid, h.h. according to the State Standard GOST $61-75^{6}$, deionized water obtained in "Milli-Q Advantage A10" system, solidphase extraction cartridges with a strong anion-exchange fixed phase 'Strata SAX' by Phenomenex (sorbent mass $500 \mathrm{mg}$, volume $6 \mathrm{~cm}^{3}$ ); special purity acid nitric oxide, concentrated in accordance with the
State Standard GOST 11125-84 ; acid citric monohydrate or anhydrous by the State Standard GOST 3652-69 ${ }^{8}$ h.h., carbamide according to the State Standard GOST 6691-779 , sodium boron hydride h.ch .; sodium hydroxide according to the State Standard GOST $4328-77^{10}$. h.p.; propanebutane, a mixture in cylinders according to the State Standard GOST 20448-90 ${ }^{11}$.

Product samples were scissor-cut into pieces of $1-3 \mathrm{~mm}$ in size, weighed to within $\pm 0.01 \mathrm{~g}$, placed in a Petri dish, frozen and vacuum-dried in LS-500 device (made in Russia). The dried samples were reweighed to determine the moisture content, and then grounded into a powder in a

2 TU 6-02-570-75. Vodoroda perekis' osoboi chistoty: tekhnicheskie ukazaniya [Hydrogen peroxide of special purity: Technical guidelines]. Rossiiskii nauchno-tekhnicheskii tsentr informatsii po standartizatsii, metrologii $i$ otsenke sootvetstviya. Available at: http://www.vniiki.ru/document/3404123.aspx (15.03.2018) (in Russian).

${ }^{3}$ GOST 6995-77. Reaktivy. Metanol-yad. Tekhnicheskie usloviya (s izmeneniyami № 1, 2): gosudarstvennyi standart Soyuza SSR [Reagents. Methanol- poison. Specifications (with Amendments 1, 2): State Standard of the USSR]. KODEKS: elektronnyi fond pravovoi i normativno-tekhnicheskii dokumentatsii. Available at: http://docs.cntd.ru/document/1200017517 (15.03.2018) (in Russian).

${ }^{4}$ GOST 3118-77 (ST SEV 4276-83). Reaktivy. Kislota solyanaya. Tekhnicheskie usloviya (s izmeneniem № 1): gosudarstvennyi standart Soyuza SSR [Reagents. Hydrochloric acid. Specifications (with Amendment No. 1): State Standard of the USSR]. KODEKS: elektronnyi fond pravovoi $i$ normativno-tekhnicheskii dokumentatsii. Available at: http://docs.cntd.ru/document/1200017281 (15.03.2018) (in Russian).

${ }^{5}$ GOST 3770-75. Reaktivy. Ammonii uglekislyi. Tekhnicheskie usloviya (s izmeneniem № 1): gosudarstvennyi standart Soyuza SSR [Reagents. Ammonium carbonate. Specifications (with Amendment No. 1): State Standard of the USSR]. KODEKS: elektronnyi fond pravovoi $i$ normativno-tekhnicheskii dokumentatsii. Available at: http://docs.cntd.ru/document/1200017294 (15.03.2018) (in Russian).

${ }^{6}$ GOST 61-75 (ST SEV 5375-85). Reaktivy. Kislota uksusnaya. Tekhnicheskie usloviya (s izmeneniyami № 1, 2, 3): mezhgosudarstvennyi standart [Reagents. Acetic acid. Specifications (with Amendments N 1, 2, 3): Inter-State Standard]. KODEKS: elektronnyi fond pravovoi i normativno-tekhnicheskii dokumentatsii. Available at: http://docs.cntd.ru/document/1200017471 (15.03.2018) (in Russian).

${ }^{7}$ GOST 11125-84. Kislota azotnaya osoboi chistoty. Tekhnicheskie usloviya (s izmeneniem № 1): mezhgosudarstvennyi standart [Nitric acid of special purity. Specifications (with Amendment No. 1): Interstate Standard]. KODEKS: elektronnyi fond pravovoi i normativno-tekhnicheskii dokumentatsii. Available at: http://docs.cntd.ru/document/1200017537 (15.03.2018) (in Russian).

${ }^{8}$ GOST 3652-69 (ST SEV 394-88). Reaktivy. Kislota limonnaya monogidrat i bezvodnaya. Tekhnicheskie usloviya (s izmeneniyami № 1,2): gosudarstvennyi standart Soyuza SSR [Reagents. Citric acid monohydrate, anhydrous. Specifications (with Amendments N 1, 2): State Standard of the USSR]. KODEKS: elektronnyi fond pravovoi i normativno-tekhnicheskii dokumentatsii. Available at: http://docs.cntd.ru/document/1200017479 (15.03.2018) (in Russian).

${ }^{9}$ GOST 6691-77 Karbamid. Tekhnicheskie usloviya (s izmeneniyami № 1, 2): mezhgosudarstvennyi standart [Carbamide. Specifications (with Amendments N 1,2): Interstate Standard]. KODEKS: elektronnyi fond pravovoi i normativno-tekhnicheskii dokumentatsii. Available at:http://docs.cntd.ru/document/1200017516 (15.03.2018) (in Russian).

${ }^{10}$ GOST 4328-77 Reaktivy. Natriya gidrookis'. Tekhnicheskie usloviya (s izmeneniyami № 1, 2): mezhgosudarstvennyi standart [Reagents. Sodium hydroxide. Specifications (with Amendments N 1, 2): Interstate Standard]. KODEKS: elektronnyi fond pravovoi i normativno-tekhnicheskii dokumentatsii. Available at:http://docs.cntd.ru/document/1200017363 (15.03.2018) (in Russian).

${ }^{11}$ GOST 20448-90 Gazy uglevodorodnye szhizhennye toplivnye dlya kommunal'no-bytovogo potrebleniya. Tekhnicheskie usloviya (s izmeneniyami № 1, 2, s popravkoi): mezhgosudarstvennyi standart [Hydrocarbon liquid petroleum gases for municipal consumption. Specifications (with Amendments N 1, 2, as amended): Interstate Standard]. KODEKS: elektronnyi fond pravovoi $i$ normativno-tekhnicheskii dokumentatsii. Available at: http://docs.cntd.ru/document/1200004726 (15.03.2018) (in Russian). 
mortar. A homogenized and shredded dry sample of 0.1-0.2 g (taken with an accuracy of $\pm 0.001 \mathrm{~g}$ ) was introduced into a sectional-view glass tube No.14, of $20 \mathrm{~cm}^{3}$, added with $10 \mathrm{~cm}^{3}$ of extraction solution (3\% by mass of hydrogen peroxide in $0.055 \mathrm{M}$ hydrochloric acid on deionized water) and placed in a water bath with a shaker at a temperature of $95^{\circ} \mathrm{C}$ for 45 minutes. The samples were then cooled to a room temperature, placed in centrifuge tubes, and centrifuged during 10 minutes in an angular rotor centrifuge at $2100 \mathrm{~g}$. The supernatants were transferred to polypropylene tubes and added with deionized water to a volume of $10 \mathrm{~cm}^{3} ; 5 \mathrm{~cm}^{3}$ of each supernatant was selected to determine the total As content using atomic absorption spectrometry; $3 \mathrm{~cm}^{3}$ was taken from the residues for further solid-phase extraction. To test the completeness of the extraction, simultaneously we took $0.1-1.0 \mathrm{~g}( \pm 0.001$ g) weighted portion of the analyzed dry sample to determine the total As content.

iAs was separated from oAs using solid phase extraction on SPE cartridges placed in a vacuum chamber. For completeness of samples solid-phase extraction we adhered to the recommended elution rate: $2 \mathrm{~cm}^{3}$ of liquid/5 min. The cartridges were pre-conditioned by $2 \mathrm{~cm}^{3}$ methanol. The sorbent balancing of cartridges was accomplished with a $2 \mathrm{~cm}^{3}$ solution consisting of equal volumes of $40 \mathrm{mM}$ ammonium carbonate and an extraction solution. Prior to being applied onto a cartridge, supernatant of $3 \mathrm{~cm}^{3}$ was mixed with $3 \mathrm{~cm}^{3}$ $40 \mathrm{mM}$ ammonium carbonate. Using a multi-purpose indicator-paper, we determined the mixture $\mathrm{pH}$, which was to correspond to $6.5 \pm 1.0$. The buffered solution of the sample was centrifuged for 10 minutes at $4000 \mathrm{rpm}$, thereupon an aliquot

Determinations of total arsenic, organic and inorganic arsenic form, in seafood samples

\begin{tabular}{|c|c|c|c|c|c|c|}
\hline \multirow{2}{*}{ No } & \multirow{2}{*}{ Sample } & \multirow{2}{*}{$\begin{array}{l}\text { Moisture } \\
\%\end{array}$} & \multirow{2}{*}{$\begin{array}{c}\text { Extraction } \\
\%\end{array}$} & \multicolumn{3}{|c|}{ As content, $\mathrm{mg} / \mathrm{kg} \mathrm{M} \pm \square^{\square}$} \\
\hline & & & & Total As & oAs & iAs \\
\hline 1 & $\begin{array}{l}\text { Shrimp, cooked-frozen, with } \\
\text { head, sample No. } 1\end{array}$ & 72,2 & 83 & $3,27 \pm 1,14$ & $1,97 \pm 0,70$ & $1,30 \pm 0,45$ \\
\hline 2 & $\begin{array}{l}\text { Shrimp, cooked-frozen, with } \\
\text { head, sample No. } 2\end{array}$ & 75,3 & $\geq 100 * *$ & $10,6 \pm 3,7$ & $7,49 \pm 2,62$ & $3,07 \pm 1,07$ \\
\hline 3 & $\begin{array}{l}\text { Whole shrimp, cooked-frozen, } \\
\text { sample No. } 3\end{array}$ & 87,5 & $\geq 100$ & $6,88 \pm 2,41$ & $5,27 \pm 1,84$ & $1,60 \pm 0,56$ \\
\hline 4 & Pacific mussels, peeled & 73,5 & $\geq 100$ & $0,70 \pm 0,24$ & $0,88 \pm 0,31$ & $\mathrm{H} / \mathrm{o}^{* * * * *}$ \\
\hline 5 & Mussels, cooked-frozen & 74,8 & $\geq 100$ & $0,81 \pm 0,28$ & $0,86 \pm 0,30$ & $\mathrm{H} / \mathrm{O}$ \\
\hline 6 & Squid trunk, sample No. 1 & 84,5 & $\geq 100$ & $0,30 \pm 0,10$ & $0,34 \pm 0,12$ & $\mathrm{H} / \mathrm{O}$ \\
\hline 7 & Squid trunk, sample No. 2 & 82,9 & $\geq 100$ & $0,25 \pm 0,09$ & $0,24 \pm 0,08$ & $\mathrm{H} / \mathrm{O}$ \\
\hline 8 & Squid No. 3 & 83,0 & $\geq 100$ & $0,04 \pm 0,01$ & $0,04 \pm 0,01$ & $\mathrm{H} / \mathrm{O}$ \\
\hline 9 & Squid No. 4 & 83,0 & 66 & $0,05 \pm 0,02$ & $0,03 \pm 0,01$ & $0,02 \pm 0,01$ \\
\hline 10 & Crab, cooked-frozen & 83,2 & 91 & $9,90 \pm 3,45$ & $6,67 \pm 2,33$ & $3,23 \pm 1,13$ \\
\hline 11 & Halibut & 76,6 & $\geq 100$ & $2,84 \pm 0,99$ & $2,15 \pm 0,75$ & $0,69 \pm 0,24$ \\
\hline 12 & Sea bass & 81,4 & $\geq 100$ & $0,49 \pm 0,17$ & $0,41 \pm 0,14$ & $0,08 \pm 0,03$ \\
\hline 13 & Navaga & 81,2 & 100 & $28,8 \pm 10,1$ & $18,9 \pm 6,6$ & $9,86 \pm 3,45$ \\
\hline 14 & Laminaria, dried & $* * *$ & $\geq 100$ & $20,3 \pm 7,1$ & $20,4 \pm 7,1$ & $\mathrm{H} / \mathrm{O}$ \\
\hline 15 & Laminaria, dry, chopped & **** & $\geq 100$ & $25,2 \pm 8,8$ & $24,5 \pm 8,6$ & $0,66 \pm 0,23$ \\
\hline 16 & Laminaria, frozen, unwashed & $* * *$ & $\geq 100$ & $17,5 \pm 6,1$ & $16,0 \pm 5,6$ & $1,54 \pm 0,54$ \\
\hline 17 & White Sea fucus, chopped & $* * *$ & $\geq 100$ & $12,3 \pm 4,3$ & $10,2 \pm 3,6$ & $2,11 \pm 0,74$ \\
\hline
\end{tabular}

Note : * - Confidence interval at a significance level of $p=0,95 ; * *$ - Completeness of extraction made $100 \%$ within determination error limits. 
of $4 \mathrm{~cm}^{3}$ was applied to the pre-sorbent equilibrated SPE cartridges installed in a vacuum chamber. After the solution passed through cartridge (for 10 minutes), it was washed with $6 \mathrm{~cm}^{3}$ of $0.5 \mathrm{M}$ acetic acid, and then dried under vacuum until complete drying. The combined solutions treated in the cartridge at this stage were an oAs fraction. The cartridge-adsorbed fraction was further eluted with $2.5 \mathrm{~cm}^{3}$ of 0.4 $\mathrm{M}$ hydrochloric acid. During an elution, iAs (V) fraction retained on SPE cartridges was collected in polypropylene tubes with further vacuum dehydration for at least 5 minutes. The initial dry product sample, an extract aliquot, oAs and iAs fractions obtained were mineralized, according to the State Standard GOST 26929-94 ${ }^{12}$. After that, the total As content was determined using an atomic-absorption spectrometer "KVANT-2A-GRG" (Russia) with a hydride accessory GGR-107. According to the State Standard GOST P 51766-2001 ${ }^{13}$ for this method of analysis, its relative error limit at 2 repetitions and a significance level in confidence interval of $95 \%$ is \pm $35 \%$, the detection threshold is $3 \times 10^{-4}$ $\mu \mathrm{g} / \mathrm{cm}^{3}$.

Results and discussion. The findings upon iAs and oAs separate determination in 17 seafood samples (shrimps, mussels, squid, sea fish and seaweed) are shown in Table.

As follows from the table, in 8 out of 17 samples analyzed (2 samples of shrimp, 1 crab, 1 fish, 4 (all analyzed) samples of algae), total As content does not correspond to the norm. However, in all these cases, iAs content in the samples was significantly lower, comparing to that of oAs. In 6 out of 17 analyzed products, within the range of detection sensitivity $(0.1 \mathrm{mg} / \mathrm{kg})$, iAs was not detected, and, apparently, As totally was represented by its organic form. The obtained data confirm the previous assumption that food products risk assessment, in terms of total As content, gives an overestimated result due to the prevalence of a relatively low-toxicity oAs in the whole As pool. As known, products of sea hydrobionts have high nutritional value, being the sources of essential minerals: iodine, selenium, etc., of dietary fiber (algae) and high-grade protein (fish and invertebrates). In view of this, the issue of obtaining scientific data on iAs content in these types of food products is topical. The procedure proposed for separate determination of oAs and iAs has good prospects, since it is relatively simple in hardware, of low cost (SPE cartridges can be reused after reconditioning many times) and, after an appropriate metrological validation, can be implemented in most laboratories certified to examine chemical safety of food products.

Funding. Studies were subsidized for the state task within the Program of Science and Research Investigations (the subject of Federal Agency for Scientific Organizations of Russia No. 05292014-0044).

A conflict of interests. The authors state there is no conflict of interests.

\footnotetext{
${ }^{12}$ GOST 26929-94. Syr'e i produkty pishchevye. Podgotovka prob. Mineralizatsiya dlya opredeleniya soderzhaniya toksichnykh elementov: mezhgosudarstvennyi standart [Raw materials and food products. Preparation of samples. Mineralization to determine the content of toxic elements: Interstate Standard]. KODEKS: elektronnyi fond pravovoi $i$ normativnotekhnicheskii dokumentatsii. Available at: http://docs.cntd.ru/document/1200021120 (15.03.2018).

${ }^{13}$ GOST R 51766-2001. Syr'e i produkty pishchevye. Atomno-absorbtsionnyi metod opredeleniya mysh'yaka: gosudarstvennyi standart RF [Raw materials and food products. Atomic Absorption Method for Determination of Arsenic: State Standard of the Russian Federation]. KODEKS: elektronnyi fond pravovoi i normativno-tekhnicheskii dokumentatsii. Available at: http://docs.cntd.ru/document/1200025461 (15.03.2018).
} 


\section{References}

1. Gomez-Caminero A., Howe P., Hughes M., Kenyon E., Lewis D.R. [et al.]. Arsenic and arsenic compounds. Geneva: World Health Organization, 2001, $521 \mathrm{p}$.

2. Dietary exposure to inorganic arsenic in the European population. EFSA Journal, 2014, vol. 12 , no. 3 , pp. 3597.

3. Environmental Health and Medicine Education. Arsenic Toxicity. Cover Page. Agency for Toxic Substances and Disease Registry. Available at: https://www.atsdr.cdc.gov/csem/csem.asp?csem $=1 \& p 0=0$ (16.03.2018).

4. Hughes M.F., Beck B.D., Chen Yu., Lewis A.S., Thomas D.J. Arsenic exposure and toxicology: a historical perspective. Toxicological Sciences, 2011, vol. 123, no. 2, pp. 305-332.

5. List of classifications, Volumes 1-121. World Health Organization: IARC Monographs on the Evaluation of Carcinogenic Risks to Humans. Available at: http://monographs.iarc.fr/ENG/Classification/latest classif.php (16.03.2018).

6. Schoof R.A., Yost L.J., Eickhoff J., Crecelius E.A., Cragin D.W., Meacher D.M., Menzel D.B. A market basket survey of inorganic arsenic in food. Food Chem. Toxicol., 1999, vol. 37, pp. 839-846.

7. Jackson B.P., Bertsch P.M. Determination of arsenic speciation in poultry wastes by icicp-ms. Environ. Sci. Technol., 2001, vol. 35, pp. 4868-4873.

8. Stolz J.F., Perera E., Kilonzo B., Kail B., Crable B., Fisher E., Ranganathan M., Wormer L., Basu P. Biotransformation of 3-nitro-4-hydroxybenzene arsonic acid (roxarsone) and release of inorganic arsenic by clostridium species. Environ. Sci. Technol., 2007, vol. 41, pp. 818-823.

9. Feldmann J., Krupp E.M. Critical review or scientific opinion paper: Arsenosugars-a class of benign arsenic species or justification for developing partly speciated arsenic fractionation in foodstuffs. Anal. Bioanal. Chem., 2011, vol. 399, pp. 1735-1741.

10. Arsenic, Metals, Fibres, and Dusts. IARC Monographs on the Evaluation of Carcinogenic Risks to Humans Volume 100C. World Health Organization: International Agency for Research on Cancer. Available at: http://publications.iarc.fr/Book-And-Report-Series/IarcMonographs-On-The-Evaluation-Of-Carcinogenic-Risks-To-Humans/Arsenic-Metals-FibresAnd-Dusts-2012 (16.03.2018).

11. Sabirova K.M., Kislitsina L.V., Kiku P.F. Otsenka riska dlya zdorov'ya naseleniya Primorskogo kraya ot vozdeistviya mysh'yaka $\mathrm{v}$ produktakh pitaniya [Risk assessment for health of population of Primorsky krai from exposure to arsenic in foods]. Zdorov'e. Meditsinskaya ekologiya. Nauka, 2017, vol. 70, no. 3, pp. 139-142 (in Russian).

12. Sabirova K.M., Kislitsyna L.V., Kiku P.F. Otsenka riska dlya zdorov'ya naseleniya ot voz-deistviya mysh'yaka [Assessment of risk for health of the population from the effects of arsenic]. Zdorov'e naseleniya i sreda obitaniya, 2017, no. 9 (294), pp. 47-51 (in Russian).

13. Valeullina N.N., Ural'shin A.G., Brylina N.A., Grechko G.Sh., Beketov A.L., Nikiforova E.V., Makhanova I.I. Soderzhanie mysh'yaka v khlebnykh produktakh i otsenka riska dlya zdorov'ya naseleniya pri ikh potreblenii [Arsenic contents in bakery and assessment of population health risk related to such products]. Aktual'nye problemy bezopasnosti i analiza riska zdorov'yu naseleniya pri vozdeistvii faktorov sredy obitaniya: Materialy VII Vserossiiskoi nauchnoprakticheskoi konferentsii s mezhdunarodnym uchastiem. In: A.Yu. Popova, N.V. Zaitseva eds. Perm, 2016, vol. 2, pp. 18-21 (in Russian).

14. Shumakova A.A., Povarova N.M., Rezaeva D.M. Soderzhanie nekotorykh toksichnykh elemen-tov v krupakh i zerne [Concentrations of some toxicants in cereals and grains]. Voprosy pitaniya, 2016, vol. 85, no. S2, pp. 39 (in Russian).

15. Chuprakova A.M., Rebezov M.B. Analiz rezul'tatov monitoringa prob myasnykh i rybnykh produktov na soderzhanie tyazhelykh metallov [The analysis of monitoring results of 
samples of meat and fish on the content of heavy metals]. Vestnik Yuzhno-Ural'skogo gosudarstvennogo universiteta. Seriya: Ekonomika i menedzhment, 2015, vol. 9, no. 2, pp. 194-201 (in Russian).

Kruglyakova U.S., Bagryantseva O.V., Evstratova A.D., Malinkin A.D., Gmoshinskii I.V., Khotimchenko S.A. Separate quontitative determination of organic and non-organic arsenic in sea products. Health Risk Analysis, 2018, no. 2, pp. 112-118. DOI: 10.21668/health.risk/2018.2.13.eng

Received: 08.05.2018

Accepted: 17.06 .2018

Published: 30.06.2018 